\title{
Pengembangan Tes Diagnostik Multi Representasi Eksternal (MRE) untuk Mengetahui Profil Kemampuan Representasi Konsep
}

\author{
Susanti Septrida Silaen ${ }^{1}$,Debora Natalia Sudjito ${ }^{2}$, Marmi Sudarmi $^{3}$ \\ Pendidikan Fisika, Fakultas Sains dan Matematika, Universitas Kristen Satya Wacana \\ santisilaen@yahoo.com
}

\begin{abstract}
ABSTRAK
Permasalahan yang teridentifikasi ialah kemampuan siswa dalam memahami konsep fisika yang beragam. Oleh karena itu tes diagnostik MRE dijadikan salah satu alternatif untuk mengatasi masalah tersebut. Tujuan penelitian adalah mengetahui profil kemampuan representasi konsep siswa dengan melihat bentuk representasi apa saja yang dapat disajikan siswa dan bagaimana kemampuan siswa dalam merepresentasikan konsep GLBB dalam format verbal, matematis, dan grafik di SMA Kristen Satya Wacana. Sampel penelitian adalah siswa kelas X yang berjumlah 25 orang. Jenis penelitian yang digunakan adalah penelitian kualitatif dan instrumen yang digunakan berupa soal uraian sebanyak 15 butir soal. Data penelitian diperoleh berdasarkan jawaban siswa yang dinilai berdasarkan rubrik penilaian yang berpedoman pada rubrik multiple representation yang dikembangkan oleh The Rutgers Physics and Astronomy Education (PAER). Hasil Penelitian menunjukkan bahwa sebesar $64 \%$ siswa mampu merepresentasikan konsep secara verbal dan matematis, sebesar $8 \%$ siswa mampu merepresentasikan konsep secara verbal dan grafik, dan sebesar $28 \%$ siswa mampu merepresentasikan konsep secara matematis, verbal, dan grafik
\end{abstract}

Kata kunci: tes diagnostik, multi representasi eksternal, kemampuan representasi konsep

\section{ABSTRACT}

The problem identified is the ability of students to understand diverse physics concepts. Therefore multiple external representation diagnostic test is used as an alternative to overcome this problem. The purpose of the research was to find out the profile of students 'representation ability by looking at what forms of representation students could give and how students' ability to represent the GLBB concept in verbal, mathematical, and graphic formats at Satya Wacana Christian High School. The research sample was 25 grade $X$ students. The type of research used is qualitative research and the instruments used are in the form of a description of 15 items. The research data was obtained based on students' answers which were assessed based on the assessment rubric which was guided by the multiple representation rubric developed by The Rutgers Physics and Astronomy Education (PAER). The research showed that 64\% of students were able to represent concepts verbally and mathematically, $8 \%$ of students were able to represent concepts verbally and graphically, and $28 \%$ of students were able to represent concepts mathematically, verbally, and graphically.

Keywords: diagnostic test, multiple external representation, concept representation ability

\section{PENDAHULUAN}

Evaluasi belajar siswa yang biasanya berupa tes bertujuan untuk mengetahui tingkat kemampuan siswa, mendiagnosis kesulitan belajar siswa, mengetahui hasil pengajaran, mengetahui hasil belajar, mengetahui pencapaian kurikulum, mendorong siswa belajar, dan mendorong guru agar mengajar lebih baik (Djemari Mardapi, 2004: 72).

Berdasarkan wawancara yang dilakukan kepada guru di salah satu SMA, untuk mengetahui sejauh mana siswa menguasai konsep, kemampuan siswa dalam mengerjakan soal-soal latihan dan ulangan diobservasi. Soal-soal ulangan biasanya disajikan dalam bentuk pilihan ganda saja atau uraian saja atau benar salah. Menurut guru tersebut, tes yang berbentuk uraian yang lebih baik digunakan karena dapat melihat sejauh mana penguasaan konsep yang dimiliki siswa. Hal ini senada dengan hasil penelitian Zidner (1987: 607), yang menyimpulkan bahwa bentuk tes uraian 
membutuhkan kemampuan yang tinggi untuk mengorganisasi jawaban, membutuhkan kemampuan untuk mengingat kembali materi, membutuhkan pengetahuan yang interaktif, dan kemampuan menulis yang baik. Pada tes pilihan berganda tidak didapatkan hal seperti itu, karena siswa tinggal memilih opsi yang telah disiapkan dan memberikan kesempatan siswa menebak jawaban benar lebih besar dibandingkan pada tes uraian (Kuechler dan Simkin, 2003).

Nilai ulangan tertinggi yang didapat siswa 100 sedangkan nilai terendah 40 . Berdasarkan nilai yang dihasilkan siswa tersebut, siswa belum memenuhi MRE karena tes yang dilakukan hanya menggunakan satu format saja. Oleh sebab itu, untuk mengatasinya perlu dilakukan penelitian untuk mengukur kemampuan MRE siswa dengan menggunakan tes diagnostik MRE. Hasil tes diagnostik MRE melihat bentuk representasi apa saja yang dapat disajikan siswa dan bagaimana kemampuan siswa dalam merepresentasikan konsep. Konsep fisika yang akan ditinjau pada penelitian ini adalah materi GLBB.

Tes diagnostik MRE meminta siswa merepresentasi ulang konsep yang sama dengan format yang berbeda, termasuk verbal, gambar, grafik, dan matematis (Prain \& Waldrip, 2007). Pada umumnya format tes yang dilakukan berupa matematis saja atau verbal saja, sehingga untuk melihat apakah siswa mampu memahami suatu konsep, belum memenuhi secara utuh. Oleh karena itu, untuk melihat sejauh mana kemampuan siswa dalam memahami suatu konsep, perlu dilakukan tes diagnostik MRE. Salah satu ciri siswa yang dapat memahami mata pelajaran fisika adalah mempunyai kemampuan untuk merepresentasikan konsep, tidak hanya mengerti tapi dapat menjelaskan dan menceritakan gagasan hasil pemikiran mereka (Prain dan Waldrip, 2010). Rumusan masalah pada penelitian ini adalah bagaimana profil kemampuan representasi konsep siswa. Tujuan penelitian untuk mengetahui profil kemampuan representasi konsep siswa sedangkan manfaat penelitian ini adalah memberi masukan pada guru bagian-bagian pembelajaran mana saja yang masih harus diperbaiki supaya siswa dapat memahami materi secara komprehensif.

\section{METODE PENELITIAN}

Jenis penelitian yang digunakan adalah penelitian kualitatif. Penelitian dilakukan pada tanggal 15 November 2018 dengan sampel penelitiannya ialah siswa kelas $\mathrm{X}$ SMA Kristen Satya Wacana yang jumlahnya 25 orang. Instrumen yang digunakan adalah tes diagnostik berupa soal uraian pada materi GLBB sebanyak 15 butir soal. Soal-soal tersebut dinyatakan valid dan layak digunakan oleh validator dan telah diuji coba ke siswa kelas XI dan XII.

Dalam fisika ada beberapa format representasi yang dapat dimunculkan, Waldrip (Mahardika, 2012) mengatakan bahwa penyajian representasi dapat dikelompokkan secara khusus seperti: 1) Format verbal, untuk memberikan definisi dari suatu konsep. 2) Format matematis, untuk menyelesaikan persoalan kuantitatif. 3) Format gambar, suatu konsep akan menjadi jelas ketika dapat direpresentasikan dalam bentuk gambar. Gambar dapat membantu memvisualisasikan sesuatu yang masih bersifat abstrak dan 4) Format grafik, penjelasan yang panjang terhadap suatu konsep dapat direpresentasikan dalam suatu grafik.

Pada tes ini kemampuan representasi verbal, matematis, dan grafik yang akan dilihat. Jawaban siswa dinilai berdasarkan rubrik penilaian yang berpedoman pada rubrik multiple representation yang dikembangkan oleh The Rutgers Physics and Astronomy Education (PAER). Untuk menilai kemampuan representasi, diberi skor dengan rentang 0 sampai 3. Skor 0 diberikan kepada siswa yang tidak dapat menjawab sama sekali (missing), skor 1 diberikan kepada siswa yang sudah merepresentasikan informasi tetapi dengan cara yang salah dan tidak sesuai dengan jawaban sebenarnya, skor 2 diberikan kepada siswa yang sudah merepresentasikan namun perlu perbaikan (need some improvement) dan skor 3 diberikan kepada siswa yang mampu merepresentasikan informasi dengan baik dan benar (Adequate). Setelah melakukan penskoran pada jawaban siswa, dihitung skor rata-rata yang diperoleh masing-masing siswa dengan menggunakan rumus: $\bar{X}=\frac{X}{X \max }$ Keterangan $: \bar{X}:$ Skor rata-rata

$X$ : Skor yang diperoleh

Xmax : Skor maksimum 


\section{HASIL \& PEMBAHASAN}

Berikut ini adalah hasil dan pembahasan terhadap profil representasi yang disajikan siswa dalam menyelesaikan soal-soal GLBB.

a. Representasi verbal

Pada representasi ini kemampuan siswa dalam menginterpretasi dan menjelaskan suatu konsep yang dilihat. Grafik rekapitulasi kemampuan siswa dalam membuat representasi verbal ditunjukkan pada Gambar 1.

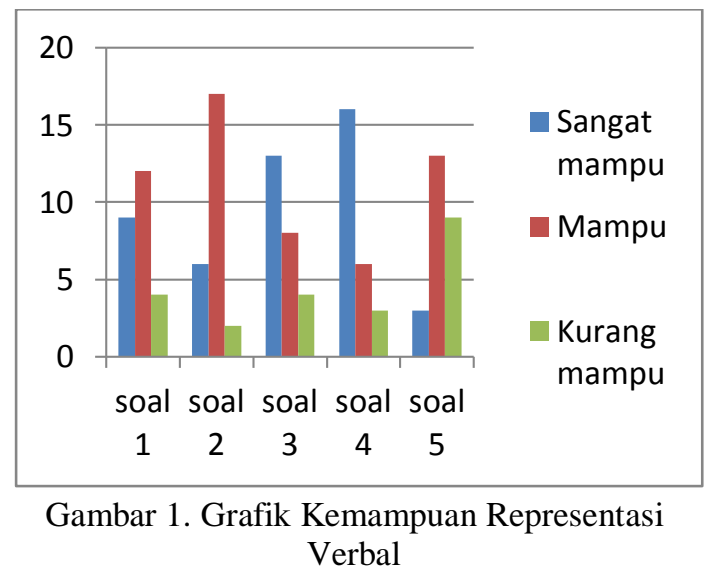

Berdasarkan hasil rekapitulasi, pada soal no 1 sebanyak 9 siswa termasuk kategori sangat mampu, pada soal no 2 sebanyak 6 siswa termasuk kategori sangat mampu, pada soal no 3 sebanyak 13 siswa yang termasuk kategori sangat mampu, dan soal no 4 paling banyak siswa yang termasuk kategori sangat mampu yaitu sebanyak 16 siswa, soal yang diberikan: Pada gerak benda vertikal ke atas, saat benda berada di puncak, apakah kecepatannya nol atau percepatannya nol? Berikan alasanmu! Jawaban siswa: kecepatannya nol; alasannya karena saat di atas benda diam. Siswa mampu menjelaskan konsep tentang gerak benda vertikal ke atas dengan benar sedangkan pada soal no 5 hanya 3 siswa yang termasuk kategori sangat mampu, soal yang disajikan seperti berikut: Percepatan dari benda yang bergerak vertikal ke bawah adalah tetap $10 \mathrm{~m} / \mathrm{s}^{2}$. Bagaimana dengan kecepatannya? berdasarkan hasil jawaban siswa, sebanyak 13 siswa menjawab salah, yaitu kecepatannya tetap dan kecepatannya nol, sedangkan 9 siswa menjawab dengan menulis kembali soalnya dan tidak menjawab apapun. Berdasarkan jawaban tersebut, pemahaman siswa tentang konsep kecepatan dan percepatan benda saat bergerak vertikal ke bawah masih perlu ditingkatkan. Jawaban yang benar adalah kecepatannya bertambah 10 $\mathrm{m} / \mathrm{s}$ tiap detik. Dari 5 soal verbal yang diberikan, responden tidak mengalami kesulitan dalam menyelesaikannya, terbukti dengan kemampuan siswa yang dapat menjelaskan dan menginterpretasi konsep dengan baik.

b. Representasi matematis

Pada representasi ini kemampuan siswa menyelesaikan persoalan kuantitatif yang dilihat. Grafik rekapitulasi kemampuan representasi matematis siswa ditunjukkan pada Gambar 2.

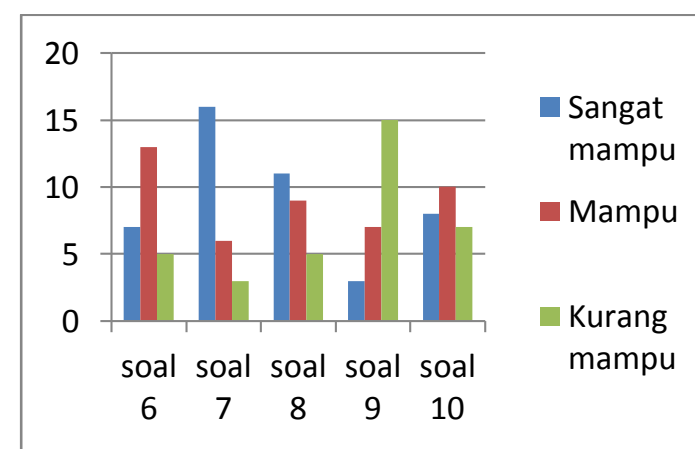

Gambar 2. Grafik Kemampuan Representasi Matematis

Berdasarkan hasil rekapitulasi, terlihat bahwa soal no 6 sebanyak 7 siswa termasuk kategori sangat mampu, pada soal no 7 paling banyak siswa termasuk kategori sangat mampu yaitu sebanyak 16 siswa, soal yang diberikan yaitu: Seorang anak melempar bola vertikal ke bawah dari tebing dengan kecepatan awal $5 \mathrm{~m} / \mathrm{s}$. Selang 1,5 sekon, kemudian ia mendengar bunyi bola mengenai tanah. Jika percepatan gravitasi di tempat itu $10 \mathrm{~m} / \mathrm{s}^{2}$ maka berapakah tinggi tebing tersebut? Sebanyak 16 siswa merepresentasikannya dengan benar, hal itu terlihat ketika menuliskan apa yang diketahui dan apa yang ditanyakan dalam soal serta menyelesaikannya dengan menggunakan rumus yang sesuai sedangkan 6 siswa penyelesaian matematisnya tidak tepat dan 3 siswa menyelesaikan dengan rumus yang tidak sesuai, rumus yang digunakan: $h=\frac{1}{2} g t^{2}$. Pada soal no 8 , sebanyak 11 siswa yang termasuk pada kategori sangat mampu sedangkan pada soal no 9 , hanya 3 siswa yang termasuk kategori sangat mampu, soal yang diberikan: Sebuah mobil bergerak dengan kecepatan tetap 54 $\mathrm{km} / \mathrm{jam}$, kemudian direm dengan gaya yang 
tetap sehingga mengalami perlambatan tetap sebesar $5 \mathrm{~m} / \mathrm{s}^{2}$. Berapakah jarak yang ditempuh mobil tersebut sampai berhenti? Sebanyak 8 siswa hanya menulis kembali informasi yang tertera pada soal dan 7 siswa tidak menuliskan apapun. 7 siswa sudah mencoba untuk menjawab, namun rumus yang digunakan salah, jawaban yang diberikan: mengkonversi kecepatan 54 $\mathrm{km} / \mathrm{jam}$ menjadi $15 \mathrm{~m} / \mathrm{s}$. Selanjutnya 4 siswa menyelesaikan dengan rumus: $s=v \times a$ dan 3 siswa menyelesaikan dengan rumus $s=\frac{V}{a}$. Pada soal no 10 , sebanyak 8 siswa termasuk kategori sangat mampu. Berdasarkan hasil jawaban pada soal no $6,7,8$, dan 10 , siswa tidak terlihat mengalami kesulitan dalam merepresentasikan konsep secara matematis, namun pada soal no 9, terlihat siswa kurang mampu memahami maksud dari soal, hal tersebut terlihat dari jawaban yang ditulis siswa. Penulisan langkah-langkah yang diketahui dalam soal belum tepat, hal ini terlihat ketika siswa tidak mengkonversi kecepatan $54 \mathrm{~km} / \mathrm{jam}$ menjadi $15 \mathrm{~m} / \mathrm{s}$ dan kesulitan dalam menentukan rumus yang tepat untuk digunakan menyelesaikan soal.

c. Representasi grafik

Pada representasi ini kemampuan siswa dalam membaca grafik, mendeskripsikan, menginterprestasi dan membuat grafik yang akan dilihat. Grafik rekapitulasi kemampuan siswa dalam membuat representasi grafik ditunjukkan pada Gambar 3.

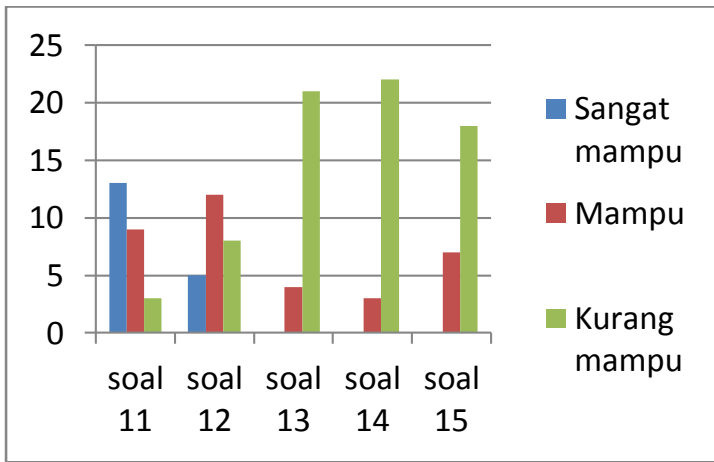

Gambar 3. Grafik Kemampuan Representasi Grafik

Berdasarkan hasil rekapitulasi, pada soal no 11 paling banyak siswa yang termasuk pada kategori sangat mampu yaitu sebanyak 13 siswa, soal yang diberikan yaitu: Perhatikan grafik $v-t$.

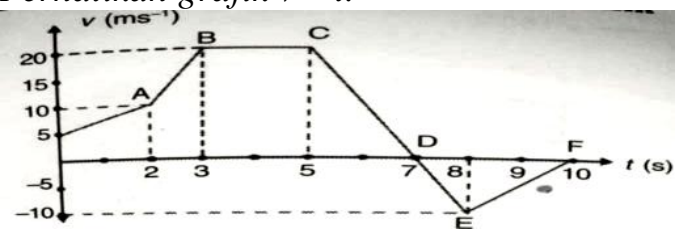

Berdasarkan grafik $v-t$.

a. Deskripsikan gerak yang terjadi dari detik ke 0 sampai detik ke 10

b. Berapakah kecepatan awal benda?

c. Berapakah percepatan yang dialami benda pada lintasan $A B$ ?

d. Berapakah percepatan yang dialami benda pada kurva BC?

e. Kapan benda mengalami perlambatan?

f. Hitung jarak yang ditempuh dari $t=2$ sekon sampai $t=3$ sekon

g. Apa jenis gerak dari $A B$ ?

h. Apa jenis gerak $B C$ ?

i. Apa jenis gerak $C D$ ?

Sebanyak 13 siswa mampu menjawab dengan benar walaupun belum lengkap. Misalnya pada poin (e), ada siswa yang menjawab bahwa benda mengalami perlambatan kurva CD. Jawaban yang benar, benda diam saat di titik $\mathrm{C}$ dan $\mathrm{E}$. Ada 9 siswa yang sudah mencoba menjawab beberapa poin dengan benar, namun pada poin (d) 4 siswa menjawab salah, siswa menjawab: $a$ pada kurva $\mathrm{BC}=\frac{20}{3-5}=2,5 \quad$ dan a pada kurva $\mathrm{BC}=\frac{20}{2}=10 \quad$ serta percepatannya tetap. Pada soal no 12 , sebanyak 5 siswa mampu menjawab benar, namun perlu lengkapi. Kesulitan yang terlihat adalah menentukan kecepatan awal pada grafik sedangkan pada soal no 13, 14, dan 15, siswa kesulitan dalam membaca dan mendeskripsikan grafik a-t dan s-t sehingga kurang mampu menyajikan kembali data/informasi pada soal ke dalam format matematis dan verbal. Dari soal 11 sampai soal 15, hanya soal no 11 dan 12 yang dapat diselesaikan dengan baik.

\section{d. Rekapitulasi MRE}

Secara keseluruhan repesentasi yang disajikan siswa dalam menyelesaikan soal-soal GLBB terangkum pada Gambar 4 


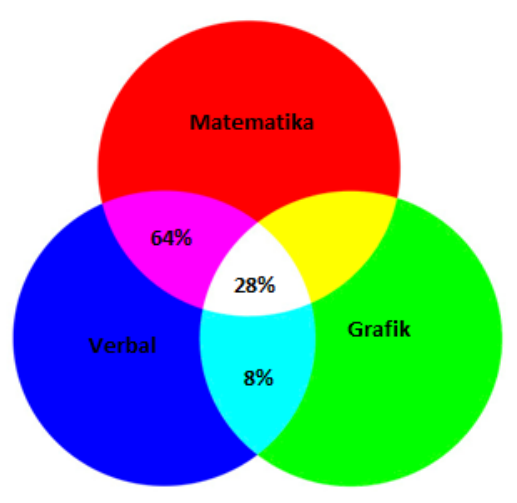

Gambar 4. Rekapitulasi MRE siswa

Siswa dikatakan memiliki kemampuan multi representasi konsep ketika dapat menyelesaikan soal-soal ke dalam format matematis, verbal dan grafik. Berdasarkan tes diagnostik MRE, diketahui sebanyak $28 \%$ siswa tergolong memiliki kemampuan MRE. Hal ini disebabkan karena siswa belum terlatih menyelesaikan soal-soal GLBB dengan format yang beragam, khususnya representasi grafik, sehingga saat menyelesaikan soal-soal pada

\section{KESIMPULAN \& SARAN}

Berdasarkan hasil penelitian ini, dapat disimpulkan bahwa siswa lebih mudah merepresentasikan konsep dalam format matematis dan verbal sedangkan pada representasi grafik, siswa kesulitan dalam membaca dan mendeskripsikan grafik.

Saran berdasarkan penelitian ini adalah siswa diajarkan menyelesaikan materi GLBB dengan format matematis, verbal dan grafik. Penelitian ini dapat dijadikan bahan penelitian lanjutan untuk melihat hal-hal yang mempengaruhi kemampuan MRE siswa dan pengumpulan data dapat dilengkapi dengan pembelajaran menggunakan pendekatan MRE, lembar observasi pembelajaran, wawancara ataupun angket kepada siswa untuk mengetahui bentuk representasi apa saja yang biasanya disajikan oleh siswa dalam menyelesaikan soal-soal GLBB.

\section{DAFTAR PUSTAKA}

Ainsworth, S. 1999. "The Functions of Multiple Representations". Computers \& Education, 33, 131-152. [Online] Tersedia:

http://www.cs.pitt.edu/chopin/references/t ig/ainsworth.pdf. [18september 2018] representasi grafik, siswa mengalami kesulitan, sedangkan sebesar $72 \%$ siswa hanya memiliki 2 kombinasi kemampuan representasi, yaitu sebesar $64 \%$ siswa mampu merepresentasikan konsep secara verbal dan matematis dan $8 \%$ siswa mampu merepresentasikan konsep secara verbal dan grafik. Berdasarkan rekapitulasi tersebut, terlihat juga siswa kurang mampu menyelesaikan soal-soal dalam format matematis dan grafik.

Ainsworth, S. 2006. "DeFT: A conceptual framework for considering learning with multiple representations ". Learning \& Instructions, 16, 183-19

Ainsworth, S."The Educational Value of Multiple -representations when Learning Complex Scientific Concepts. Theory and Practice in Science Educations, 191-208

Djemari Mardapi. (1999). Estimasi kesalahan pengukuran dalam bidang pendidikan dan implementasinya pada ujian nasional. Yogyakarta: Universitas Negeri Yogyakarta.

Dolin, J. (2001). Representational form in physics. In D. Psillos, P. Kariotoglou, V. Tselfes, G. Bisdikian, G. Fassoulopoulos, E. Hatzikraniotis, E. Kallery (Eds.). Science education research in the knowledge-based society. Proceedings of the Third International Conference of the ESERA (pp. 359-361)

Hughes, A. (2003). Testing for language teacher. New York: Cambridge University Press.

Hwang, et al. (2007). Multiple Representation Skills and Creativity Effects on Mathematical Problem Solving using a Multimedia Whiteboard System.

Kohl, P.B., Rosengrant, D., \& Finkelstein, N. D. 2007. Strongly and weekly directed 
approach to teaching multiple representation use in physics. Physical Review Special Topics-Physics Education Research. 3, 010108

Mahardika, I.K. 2012. Model Inkuiri Untuk Meningkatkan Kemampuan Representasi Verbal dan Matematis Pada Pembelajaran Fisika di SMA. Jurnal Pembelajaran Fisika, ISSN NO. 2301-9794

Prain, V. \& Wadrip, B.G. 2007. An Exploratory Study of Teachers' and Students' Use of Multi-Modal Representations of Concepts Primary Science. International Journal of Science Educations. 28 (15) 1843-1866.

Rizky, Tomo, Haratua (2014). Kemampuan Multirepresentasi Siswa SMA dalam Menyelesaikan Soal-Soal Hukum Newton. [Online].

http://jurnal.untan.ac.id/index.php/jpdpb/a rticle/view/6733Suhandi, A. (2012). Pendekatan Multi Representasi Dalam Pembelajaran Usaha-Energi dan Dampak Terhadap Pemahaman Konsep Mahasiswa.

Scaife. M., \& Rogers. Y. (1996). External Cognition: How do graphical representation work? International Journal of Human-Computer Studies. 45(2). 185-213.

Suhandi, A. (2012). Pendekatan Multi Representasi Dalam Pembelajaran Usaha-Energi dan Dampak Terhadap Pemahaman Konsep Mahasiswa.

Sutopo, dkk. 2012. Impact Of Representational Approach On The Improvement Of Students' Understanding Of Acceleration. Jurnal Pendidikan Fisika Indonesia. 8 151-173

Schwonke, R, dkk. (2009). "How Multiple External Representations Are Used and How They Can Be Made More Useful" International Journal. 23: 1227-

Ulfarina, L. (2011). Penggunaan Pendekatan Multi Representasi pada Pembelajaran Konsep Gerak untuk Meningkatkan Pemahaman Konsep dan Memperkecil Kuantitas Miskonsepsi Siswa SMP

Waldrip, B, dkk. (2006). "an Exploratory Study of Teachers' and Students' Use of Multi-modal Representations of Concepts in Primary Science” International Journal of Science Education. 28, (15), 1843-1896 